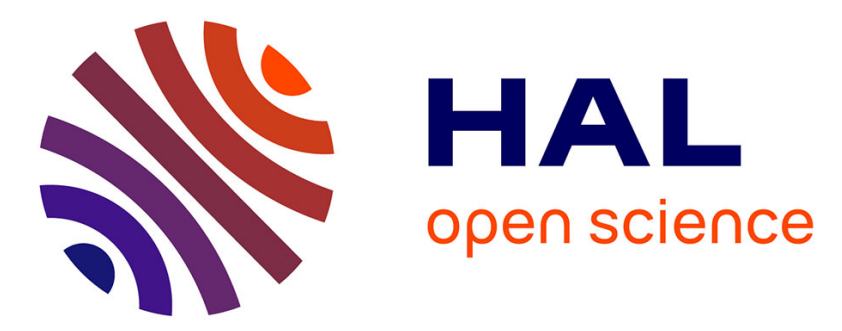

\title{
Microalgae cultivation in urban wastewater: Nutrient removal and biomass production for biodiesel and methane
}

M.P. Caporgno, Ahmed Taleb, M. Olkiewicz, J. Font, Jeremy Pruvost, J. Legrand, C. Bengoa

\section{To cite this version:}

M.P. Caporgno, Ahmed Taleb, M. Olkiewicz, J. Font, Jeremy Pruvost, et al.. Microalgae cultivation in urban wastewater: Nutrient removal and biomass production for biodiesel and methane. Algal Research - Biomass, Biofuels and Bioproducts, 2015, 10, pp.232-239. 10.1016/j.algal.2015.05.011 . hal-02534125

\section{HAL Id: hal-02534125 \\ https://hal.science/hal-02534125}

Submitted on 20 Apr 2020

HAL is a multi-disciplinary open access archive for the deposit and dissemination of scientific research documents, whether they are published or not. The documents may come from teaching and research institutions in France or abroad, or from public or private research centers.
L'archive ouverte pluridisciplinaire HAL, est destinée au dépôt et à la diffusion de documents scientifiques de niveau recherche, publiés ou non, émanant des établissements d'enseignement et de recherche français ou étrangers, des laboratoires publics ou privés. 


\title{
Microalgae cultivation in urban wastewater: Nutrient removal and biomass production for biodiesel and methane
}

\author{
M.P. Caporgno ${ }^{\text {a }}$, A. Taleb ${ }^{\mathrm{b}}$, M. Olkiewicz ${ }^{\mathrm{a}}$, J. Font ${ }^{\mathrm{a}}$, J. Pruvost ${ }^{\mathrm{b}}$, J. Legrand ${ }^{\mathrm{b}}$, C. Bengoa ${ }^{\mathrm{a}, *}$ \\ a Departament d'Enginyeria Química, Universitat Rovira i Virgili, Av. Països Catalans 26, 43007 Tarragona, Spain \\ b GEPEA, Université de Nantes, CNRS, UMR6144, bd de l'Université, CRTT - BP 406, 44602 Saint-Nazaire Cedex, France
}

\begin{abstract}
A B S T R A C T
The freshwater microalgae species Chlorella kessleri and Chlorella vulgaris, and the marine microalgae species Nannochloropsis oculata were cultivated in urban wastewater. The freshwater species demonstrated the possibility of growing in urban wastewater reaching high biomass production and nutrient removal when cultured in batch mode using a flat-panel airlift photobioreactor. Both microalgae species reached high biomass dry weights, $2.70 \pm$ $0.08 \mathrm{~g} / \mathrm{L}$ and $2.91 \pm 0.02 \mathrm{~g} / \mathrm{L}$ respectively, accompanied by nitrogen concentration reduction around $96 \%$ and $95 \%$, and a phosphorous concentration reduction around $99 \%$ and $98 \%$ respectively. N. oculata was able to uptake nutrients from wastewater to grow but with less efficiency, indicating the need of microalgae acclimation or process optimisation to achieve high nutrient removals. During C. kessleri and C. vulgaris cultivation, the nitrogen consumption led to a progressive $\mathrm{N}$-starvation process which increased the microalgae potential for biofuels production; both species produced $346 \pm 3 \mathrm{~mL}_{\mathrm{CH}_{4}} / \mathrm{g}_{\mathrm{vs}}$ and $415 \pm 2 \mathrm{~mL}_{\mathrm{CH}_{4}} / \mathrm{g}_{\mathrm{vs}}$ during anaerobic digestion, and $7.4 \pm 0.2 \mathrm{~g}_{\text {Biodiesel }} / 100 \mathrm{~g}_{\mathrm{vs}}$ and $11.3 \pm 0.1 \mathrm{~g}_{\text {Biodiesel }} / 100 \mathrm{~g}_{\mathrm{vs}}$ respectively.
\end{abstract}

\section{Introduction}

Microalgae are able to convert solar energy and carbon dioxide into energy as a result of their photosynthetic activity; when converted into biodiesel or methane, this energy could meet the population energy needs [1]. The microalgae cultivation with energetic purposes started years ago when microalgae, able to accumulate a high amount of lipids, appeared as promising crop substitute in biodiesel production [2]. Currently, crops are the common feedstocks in the biodiesel production industry but also in the food industry, thus the crop-based biofuels production has created increased food prices [3]. A wide variety of microalgae species reach higher lipid productivities than crops [2], becoming potential substrates to alleviate the referred to "food-versusfuel competition" [3]. Despite the efforts made, the industrial biodiesel production from microalgae is not economically viable nowadays due especially to the high costs for drying and lipid extraction among other costs [4]. On the contrary, the anaerobic digestion process converts wet biomass into methane [5], and energy is recovered not only from the lipid fraction.

The anaerobic digestion process is a widely known technology, currently used in the wastewater treatment plants (WWTPs). The sewage sludge, a waste produced during the wastewater treatment, generates high operating costs in its final disposal [5]; the anaerobic digestion process converts the sludge into a stable product with simultaneous

\footnotetext{
* Corresponding author.

E-mail address: christophe.bengoa@urv.cat (C. Bengoa).
}

generation of a valuable by-product such us methane. Methane utilisation contributes favourably to reduce the high operating costs generated by the final disposal of sewage sludge [5].

The nutrient level in wastewaters might be another problem in WWTPs. The water discharge with high nutrient levels cause eutrophication problems, thus the Directive 98/15/EEC establishes nutrient levels or minimum percentage of reduction before water discharge [6]. Although the nutrient concentration varies from a WWTP to another, and between the wastewater streams in the process, the stream generated during the digested sludge dewatering process always has higher nitrogen and phosphorus concentrations than in any other streams [7]. This stream, named centrate, is usually recycled for further treatment to avoid environmental problems, but it increases the WWTP costs [7]. Microalgae cultivation offers a solution to reduce the high nutrient content in centrate since microalgae consume nutrients when growing [8]. Moreover, in a waste-to-value approach, the produced biomass constitutes a by-product which could be used for various purposes, including biofuels.

Some freshwater microalgae species have already been cultured in different wastewater streams, with the purpose of reducing the nutrient concentration in wastewater or producing lipids for biofuels [7,9-13]. Similarly, seawater microalgae species have also been cultured using wastewaters despite the salinity requirements [14,15]. However, the centrate utilisation for microalgae cultivation is scarce; most of the studies were done using wastewater with a low nutrient content compared to the centrate. The use of centrate as nutrient medium allows coupling the wastewater treatment and the microalgae cultivation process with a 
minimum modification in the WWTP facilities. Wastewater treatment by microalgae cultivation is still limited, and the waste activated sludge (WAS) process is the conventional treatment in WWTP [8]. The substitution of the WAS process implies a full modification of the WWTP scheme, whereas the centrate utilisation in microalgae cultivation only needs a cultivation unit coupling.

This study analyses the possibility of coupling microalgae cultivation in WWTPs, removing nutrients from the centrate while producing biomass with energy recovery purposes. Due to the high nutrient level in the centrate which can inhibit the cell growth, the first studies aimed to determine the most suitable media for $C$. kessleri, $C$. vulgaris and Nannochloropsis oculata cultivation. The microalgae species were cultivated in different dilutions of the centrate; the dilutions were carried out with wastewater before the primary settling tank for the cultivation of freshwater microalgae species, or with natural seawater for the marine microalgae species. After the culture medium screening, the microalgae species were cultured in the most suitable medium, where the nutrient removal and the biomass production were evaluated. Finally, the harvested biomass was used for methane and biodiesel production.

\section{Materials and methods}

\subsection{Pre-treatments and characteristics of the wastewaters}

Wastewater samples from the WWTP of Saint Nazaire (ACCUEIL CARENE, Saint-Nazaire, France) were used as cultured medium for microalgae cultivation; they consisted of the centrate and the wastewater from a line before the primary settling tank. For marine microalgae cultivation, natural seawater was collected from the coastal area of Saint-Nazaire in France.

Large solid particles were first removed by centrifugation and then, the samples were filtered through a $0.45 \mu \mathrm{m}$ pore size filter to remove undesirable small particles. The total nitrogen (TN), ammonia nitrogen $\left(\mathrm{NH}_{3}-\mathrm{N}\right)$, nitrate nitrogen $\left(\mathrm{NO}_{3}-\mathrm{N}\right)$, nitrite nitrogen $\left(\mathrm{NO}_{2}-\mathrm{N}\right)$, phosphate phosphorus $\left(\mathrm{PO}_{4}-\mathrm{P}\right)$, and chemical oxygen demand (COD) were determined following the Hach DR 2800 Spectrophotometer Manual using the HACH LANGE cuvette tests and following the procedure specified for each test (Hach, 2008). The characteristics of the wastewaters and the natural seawater can be observed in Table 1.

As can be observed, the composition of the wastewater sampled before the primary settling tank composition is given as a range rather than the average value with the standard deviation; two different samples collected in different opportunities were used in the experiments. These differences in the nutrient content were taken into account for the cultured medium preparation.

Table 1

Characteristics of the wastewater and the natural seawater used for microalgae cultivation.

\begin{tabular}{|c|c|c|c|}
\hline \multirow[t]{2}{*}{ Parameter } & \multicolumn{3}{|c|}{ Water for microalgae cultivation } \\
\hline & $\begin{array}{l}\text { Before the primary } \\
\text { settling tank }^{\mathrm{a}}\end{array}$ & Centrate & Natural seawater \\
\hline $\mathrm{pH}$ & $7.42-7.79$ & $8.2 \pm 0.1$ & $7.7 \pm 0.1$ \\
\hline $\mathrm{COD}(\mathrm{mg} / \mathrm{L})$ & $95-169$ & $706 \pm 9$ & - \\
\hline $\mathrm{TN}(\mathrm{mg} \mathrm{N} / \mathrm{L})$ & $39-65$ & $1233 \pm 78$ & n.d. \\
\hline $\mathrm{NH}_{4}^{+}\left(\mathrm{mg} \mathrm{NH}{ }_{4}-\mathrm{N} / \mathrm{L}\right)$ & $36-62$ & $1198 \pm 81$ & n.d. \\
\hline $\mathrm{NH}_{4}-\mathrm{N} / \mathrm{TN}(\%)$ & $95 \pm 2$ & $98 \pm 1$ & - \\
\hline $\mathrm{NO}_{3}^{-}\left(\mathrm{mg} \mathrm{NO}_{3}-\mathrm{N} / \mathrm{L}\right)$ & $0.1-0.9$ & $2.34 \pm 0.11$ & $6.2 \pm 0.1$ \\
\hline $\mathrm{NO}_{2}^{-}\left(\mathrm{mg} \mathrm{NO}{ }_{2}-\mathrm{N} / \mathrm{L}\right)$ & $0.1-0.4$ & $0.14 \pm 0.02$ & n.d \\
\hline $\mathrm{P}\left(\mathrm{mg} \mathrm{PO}_{4}-\mathrm{P} / \mathrm{L}\right)$ & $3.1-5.4$ & $11.90 \pm 0.10$ & n.d. \\
\hline Salinity (\%o) & - & - & $28 \pm 0.5$ \\
\hline
\end{tabular}

n.d.: not detected.

a Parameter ranges from two different samples collected in two different opportunities.

\subsection{Microalgae cultivation}

\subsubsection{Shake flasks}

Three different microalgae species were cultured. The freshwater microalgae species Chlorella kessleri (strain UTEX2229) and Chlorella vulgaris (strain CCAP211/19) were obtained from the collection of algae at the University of Nantes; and the marine microalgae species N. oculata, from the Alphabiotech collection (Asserac, France).

The microalgae were first inoculated in shake flasks. The freshwater microalgae species in $250 \mathrm{~mL}$ Erlenmeyer flask containing a modified Bold Basal Medium (BBM) and the marine microalgae species, in filtered and sterilised seawater with salinity adjusted at $25 \%$ and enriched with Conway medium ( $3 \mathrm{~mL} / \mathrm{L}$ of seawater). The detailed composition of the modified BBM and Conway medium is given in Pruvost et al. [16,17].

\subsubsection{Culture medium screening in Efficient Overproducing Screening} System-Photobioreactors (EOSS-PBR)

The EOSS-PBR was especially developed for the fast screening of culture media and microalgae species in conditions representative of PBR cultivation. It consisted of six small-scale photobioreactors (bubble columns) run in parallel, each tube having a volume $V_{\mathrm{r}}=3 \cdot 10^{-5} \mathrm{~m}^{3}$, an illuminated area of $S_{\mathrm{L}}=0.008 \mathrm{~m}^{2}$ and a specific illuminated area of $\mathrm{a}_{\text {light }}=\mathrm{S} / \mathrm{V}_{\mathrm{r}}$ of $266.71 / \mathrm{m}$. A full description of the EOSS-PBR is done in Taleb et al. [18].

The culture medium was prepared by diluting the centrate to reduce the high TN concentration, either with wastewater or with natural seawater (Table 1). Before inoculation, the culture medium was filtered through a $0.45 \mu \mathrm{m}$ pore size filter to remove undesirable small particles. The TN concentrations in the culture medium for the freshwater microalgae species were $30 \mathrm{mg} \mathrm{N} / \mathrm{L}(0.002 \mathrm{~mol} / \mathrm{L}), 140 \mathrm{mg} \mathrm{N} / \mathrm{L}$ (0.010 mol/L), $260 \mathrm{mg} \mathrm{N} / \mathrm{L}(0.019 \mathrm{~mol} / \mathrm{L}), 490 \mathrm{mg} \mathrm{N} / \mathrm{L}(0.035 \mathrm{~mol} / \mathrm{L})$, $700 \mathrm{mg} \mathrm{N} / \mathrm{L}(0.050 \mathrm{~mol} / \mathrm{L})$ and $1200 \mathrm{mg} \mathrm{N} / \mathrm{L}(0.086 \mathrm{~mol} / \mathrm{L})$. For the marine microalgae species cultivation, the TN concentrations were $6 \mathrm{mg} \mathrm{N} / \mathrm{L}(<0.001 \mathrm{~mol} / \mathrm{L}), 71 \mathrm{mg} \mathrm{N} / \mathrm{L}(0.005 \mathrm{~mol} / \mathrm{L}), 135 \mathrm{~N} \mathrm{mg} \mathrm{N} / \mathrm{L}$ (0.010 mol/L), $265 \mathrm{mg} \mathrm{N} / \mathrm{L}(0.019 \mathrm{~mol} / \mathrm{L}), 524 \mathrm{mg} \mathrm{N} / \mathrm{L}(0.037 \mathrm{~mol} / \mathrm{L})$ and $782 \mathrm{mg} \mathrm{N} / \mathrm{L}(0.056 \mathrm{~mol} / \mathrm{L})$.

The $\mathrm{pH}$ in the culture medium was around 7.5 for the freshwater microalgae species and 8 for the marine microalgae species, according to Pruvost et al. and Taleb et al. [17,18]. The culture agitation was provided by continuous injection of air with 2 vol.\% $\mathrm{CO}_{2}$ at a flow rate of $3 \mathrm{~mL} / \mathrm{min}$; the incident photon flux density (PFD), by a set of 6 fluorescent white tubes was $\sim 150 \mu \mathrm{mol} / \mathrm{m}^{2} \cdot \mathrm{s}$. The temperature was regulated at $25^{\circ} \mathrm{C}$ by ambient air flow. The reactor was operated in batch mode.

The microalgae growth was evaluated following the evolution of the number of cells as a function of time $(t)$. Cell concentration $N$ expressed as number of cells per millilitre of culture was determined under an optical microscope (Axiostar-Plus, Carl Zeiss, Germany) using Malassez counting cell. The chlorophyll fluorescence in the microalgae was observed in the microscope, using the green filter set 530-585 (BP 530-585 as exciter filter, FT 600 as chromatic beam splitter and LP 615 as barrier filter; Zeiss, Oberkochen, Germany). The algal dry weight concentration $(\mathrm{Cx})$ was determined at the end of the experiment, by filtration through a pre-dried and pre-weighed glass-fibre filter (Whatman $\mathrm{GF} / \mathrm{F}$ ). The filters were dried for $24 \mathrm{~h}$ at $105^{\circ} \mathrm{C}$, cooled down in a desiccator and then weighed again. The total pigment content was determined using a spectrophotometric method, following the procedure described in [17].

\subsubsection{Microalgae cultivation in flat-panel airlift photobioreactor (PBR)}

Once the culture medium was defined, microalgae were cultured in batch mode using a flat-panel airlift PBR with $\mathrm{V}_{\mathrm{r}}=10^{-3} \mathrm{~m}^{3}$, and depth of culture of $\mathrm{L}_{\mathrm{z}}=3 \cdot 10^{-2} \mathrm{~m}$, a $\mathrm{S}_{\mathrm{L}}=8 \cdot 10^{-3} \mathrm{~m}^{2}$ and a $\mathrm{a}_{\text {light }}=33.31 / \mathrm{m}$. Before inoculation, the cells were centrifuged for $3 \mathrm{~min}$ at $6000 \times \mathrm{g}$ at room temperature, and the cell pellets were washed with the decided culture medium twice before finally suspending cells. 
The temperature was $25^{\circ} \mathrm{C}$, regulated by ambient air flow. The pH was monitored with a sensor inside the reactor (Mettler Toledo SG 3253) and automatically regulated by $\mathrm{CO}_{2}$ injection, at 7.5 for the freshwater microalgae species and 8 for the marine microalgae species. The culture agitation was provided by air bubbling. A constant PFD $\left(\sim 100 \mu \mathrm{mol} / \mathrm{m}^{2} \cdot \mathrm{s}\right)$ was used during the experiments.

The microalgae growth and the $\mathrm{Cx}$ were evaluated during cultivation as described in Section 2.2.2. The different nutrient concentrations during cultivation were determined as described in Section 2.1.; the samples were taken from the reactor, centrifuged and the supernatant analysed. The evolution of proteins, carbohydrates and lipids in the biomass during cultivation was followed with infrared spectra of the microalgae cells; the spectra were obtained in a Bruker Tensor 27 FTIR spectrometer equipped with the ATR platinum module, with a deuterated triglycine sulfate detector RT-DLaTGS and OPUS v7.0.122 software (Bruker Optics, Germany). After finishing the experiment, the biomass was recovered by centrifugation and dried using freeze-drying equipment (FT33-A Freeze Drier, Armfield Inc.) for $48 \mathrm{~h}$ to avoid major changes on its composition. The carbohydrate content in biomass was quantified by the phenol-sulphuric acid method and protein content, by the Lowry method as described in Caporgno et al. [19].

\subsection{Methane and biodiesel production}

Anaerobic digestion was carried out by triplicate, in $120 \mathrm{~mL}$ serum bottles sealed with a septum and an aluminium crimp. The inoculum consisted of mesophilic digested sludge taken from an anaerobic semicontinuous plant; the substrates were the freeze-dried microalgae species re-suspended in deionised water. The final volume in the reactors was adjusted to $80 \mathrm{~mL}$ before sealing, then the reactors were purged with nitrogen to assure anaerobic conditions and placed into an oven at $33{ }^{\circ} \mathrm{C}$; a detailed procedure is described in Caporgno et al. [19]. The amount of substrate loaded in reactors was calculated based on the organic matter added per inoculum content, the substrate to inoculum

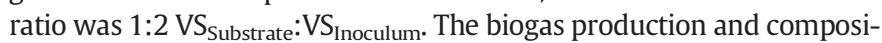
tion, and parameters after anaerobic digestion such as the volatile fatty acid concentration (VFA) were measured as described in Caporgno et al. [19]. The ammonia concentration at the end of the experiment was measured with an ion selective electrode (ISE) (Ammonia Gas Sensing combination electrode, mod. 51927-00, HACH); the alkalinity was analysed according to the standard method 2320B [20]. The theoretical methane production was calculated based on the microalgae composition, and the biodegradability of the biomass, as the fraction of the theoretical methane production reached at the end of the anaerobic digestion experiment as described in Caporgno et al. [19].

The freeze-dried microalgae biomass was converted to FAMEbiodiesel by direct transesterification procedure according to Johnson and Wen [21]. The FAMEs were analysed by GC-FID according to the Agilent Application Note 228-398 using a HP-INNOWax column (19091 N-133), and a 37 component FAME standard mixture (Supelco: $47885-U)$ was used for calibration of the method.

\section{Results and discussion}

\subsection{Culture medium screening in EOSS-PBR}

The Fig. 1a shows the evolution of the number of cells over time for C. kessleri, in nutrient media containing from $30 \mathrm{mg} \mathrm{N} / \mathrm{L}$ to $1200 \mathrm{mg} \mathrm{N} / \mathrm{L}$. As can be observed in Table 1, although the differences in the TN concentration in both wastewaters, most of the $\mathrm{N}$ content in both wastewaters is in the form of $\mathrm{NH}_{4}^{+}$.

In the nutrient medium with the lowest TN concentration, the curve follows a typical evolution for batch cultivation. There was a lag phase at the beginning, characterised by a period of physiological adjustment due to changes in the nutrient conditions. The cells adapted to the new conditions after 2 days and the growth accelerated; this is the exponential growth phase. Finally, there was no growth after day 9; this is the stationary phase. As observed in Fig. 1, when the TN concentration increased from 30 until $140 \mathrm{mg} \mathrm{N} / \mathrm{L}$, the lag phase became longer and the growth rate during the exponential growth phase became lower. There was not any microalgae cell growth at a TN concentration higher than $140 \mathrm{mg} \mathrm{N} / \mathrm{L}$; in fact, the number of cells decreased and no cells were observed after 3 days of cultivation, suggesting inhibition of the cell growth. In the centrate, there was a high level of $\mathrm{N}$ in the form of ammonium, and although it can be used by microalgae as a source of $\mathrm{N}$, it can also inhibit microalgae growth [8]. Microalgae cells were recovered from the bottom of the reactors, and their appearance was observed in the microscope also using the green filter for chlorophyll fluorescence observation. The cells in the media with $30 \mathrm{mg} \mathrm{N} / \mathrm{L}$ were smaller than in the media with $140 \mathrm{mg} \mathrm{N} / \mathrm{L}$. This result agreed with the dry weight analysis results, which determined similar algal dry weight in both media, in spite of the higher number of cells in the media with $30 \mathrm{mg} \mathrm{N} / \mathrm{L}$. Regarding the microalgae recovered from the reactors with a nitrogen concentration higher than $140 \mathrm{mg} \mathrm{N} / \mathrm{L}$, the cells presented an absence or much less florescence intensity than that recovered from reactors with 30 and $140 \mathrm{mg} \mathrm{N} / \mathrm{L}$, indicating that nitrogen concentrations higher than $140 \mathrm{mg} \mathrm{N} / \mathrm{L}$ affect the cells negatively. Comparable results were reported for $C$. vulgaris cultivation on wastewater with a high concentration of $\mathrm{NH}_{4}^{+}-\mathrm{N}$ [12].

At the end of the experiment, the algal dry weight was determined in the reactors. The $\mathrm{Cx}$ was similar in nutrient media with $30 \mathrm{mg} \mathrm{N} / \mathrm{L}$ and $140 \mathrm{mg} \mathrm{N} / \mathrm{L}, 1.34 \pm 0.10 \mathrm{~g} / \mathrm{L}$ and $1.32 \pm 0.06 \mathrm{~g} / \mathrm{L}$ respectively, in spite of the differences in the number of cells. At TN concentrations higher than $140 \mathrm{mg} \mathrm{N} / \mathrm{L}$, microalgae cells settled and Cx was lower than $0.05 \mathrm{~g} / \mathrm{L}$, as was expected due to inhibition. The total pigment content was analysed at the end of the experiment, due to the more intense green colour observed in the reactor with a TN concentration of $140 \mathrm{mg} \mathrm{N} / \mathrm{L}$ compared with $30 \mathrm{mg} \mathrm{N} / \mathrm{L}$, although the lower number of cells. The results indicated that the total pigment content was $15 \pm$ $0.1 \mu \mathrm{g} / \mathrm{mL}$ for $140 \mathrm{mg} \mathrm{N} / \mathrm{L} 1.8 \pm 0.1 \mu \mathrm{g} / \mathrm{mL}$ for $30 \mathrm{mg} \mathrm{N} / \mathrm{L}$, as was also observed elsewhere [12].

Based on the results, it was decided that a nutrient medium with a TN concentration around $140 \mathrm{mg} \mathrm{N} / \mathrm{L}$ is the most suitable for $C$. kessleri species cultivation; this allows the usage of the highest amount of the centrate and produces a high biomass concentration. Furthermore, since similar growth evolution and biomass production was reported for C. kessleri and C. vulgaris cultivation in wastewater [13], no screening was carried out with $C$. vulgaris species and the same nutrient medium was used for both species.

Regarding the culture medium for the marine microalgae species $N$. oculata, Fig. 1b shows microalgae growth in the nutrient media containing from $6 \mathrm{mg} \mathrm{N} / \mathrm{L}$ to $782 \mathrm{mg} \mathrm{N} / \mathrm{L}$. Centrate and seawater mixing affects medium salinity due to a dilution effect; the higher the amount of the centrate in the nutrient medium, the higher the TN concentration but the lower the salinity. The highest salinity was $28 \%$ in pure seawater with a low TN concentration due to the $\mathrm{NO}_{3}^{-}$presence; the lowest was $3 \%$ with a TN concentration of $782 \mathrm{mg} \mathrm{N} / \mathrm{L}$.

As can be observed in Fig. 1b, there was not a significant microalgae growth in natural seawater due to the low nutrient content. However, a higher $\mathrm{N}$ content after the centrate addition was enough to increase the number of cells. In the medium with $71 \mathrm{mg} \mathrm{N} / \mathrm{L}$ and 24\% salinity, $N$. oculata cultivation shows good results. The evolution of the number of cells shows a lag phase during the first 2 days and then, the growth accelerates almost continuously. Finally, by the 10th day, it seems that microalgae growth is close to the stationary phase. The increases in the TN concentration up to 135 and $265 \mathrm{mg} \mathrm{N} / \mathrm{L}$ decreased the salinity of the medium, $18 \%$ and $12.5 \%$ respectively. As can be seen in the curves, the microalgae did not grow in the medium with $135 \mathrm{mg} \mathrm{N} / \mathrm{L}$ in spite of the higher salinity of this medium, but they grew in the medium containing $265 \mathrm{mg} \mathrm{N} / \mathrm{L}$. In this medium, the evolution of the number of cells followed a 2 day lag phase and an exponential growth and a stationary phase around the 8th day. These results indicated inhibition 

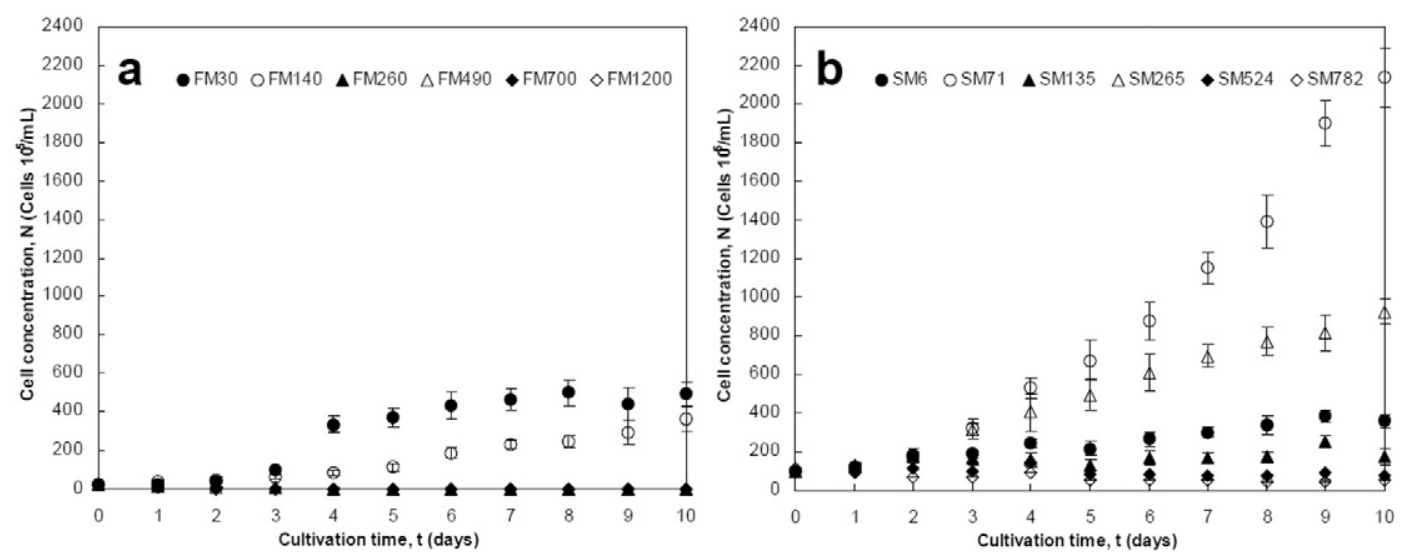

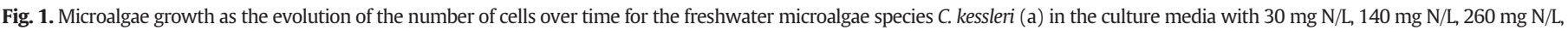

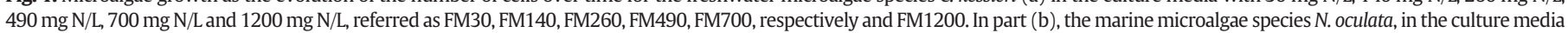
with 6 mg N/L, 71 mg N/L, 135 N mg N/L, 265 mg N/L, 524 mg N/L and 782 mg N/L, referred as SM6, SM71, SM135, SM265, SM524 and SM782, respectively. 2-Column fitting image.

in the culture medium with $135 \mathrm{mg} \mathrm{N} / \mathrm{L}$; however, the inhibition could not be attributed to a high TN concentration or to a low salinity. Comparing the media containing $71 \mathrm{mg} \mathrm{N} / \mathrm{L}$ and $265 \mathrm{mg} \mathrm{N} / \mathrm{L}$, the number of cells decreased by almost $50 \%$ due to the low salinity; the optimum salinity for $N$. oculata has been suggested between $22 \%$ and $25 \%$ and the changes in the medium salinity affect $N$. oculata cultivation [22]. It was reported that Nannochloropsis sp. grew in wastewater with 33\%。 and $18.5 \%$ o salinity ( $11 \mathrm{mg} \mathrm{N} / \mathrm{L}$ and $55 \mathrm{mg} \mathrm{N} / \mathrm{L}$ respectively), but the culture failed at lower salinities due to osmotic stress [14]. Furthermore, it was reported that Nannochloropsis salina grew in wastewater reaching similar productivities when the salinity was adjusted, and the TN was in a range between $80 \mathrm{mg} \mathrm{N} / \mathrm{L}$ and $480 \mathrm{mg} \mathrm{N} / \mathrm{L}$ [15]. Based on this, it was confirmed that the inhibition in the media with $130 \mathrm{mg} \mathrm{N} / \mathrm{L}$ was not attributable to salinity or TN concentration in the medium. A possible reason was $\mathrm{pH}$; it was reported that $\mathrm{pH}$ affects Nannochloropsis sp. significantly [23] and in the experiment, this parameter was not automatically regulated. During ammonia assimilation by microalgae, the $\mathrm{pH}$ of the medium decreases and may reach levels near $\mathrm{pH} 3$; the $\mathrm{pH}$ shifts might cause growth inhibition [24].

At $71 \mathrm{mg} \mathrm{N} / \mathrm{L}$ and $24 \%$ s salinity in nutrient medium, the Cx was $1.07 \pm 0.07 \mathrm{~g} / \mathrm{L}$. The TN concentration increased to $265 \mathrm{~N} / \mathrm{L}$ decreased the $\mathrm{Cx}$ to $0.48 \pm 0.02 \mathrm{~g} / \mathrm{L}$. In other culture media, the $\mathrm{Cx}$ was lower than $0.02 \mathrm{~g} / \mathrm{L}$, as was expected due to the inhibition observed.

Assuming that inhibition in the medium with $135 \mathrm{mg} \mathrm{N} / \mathrm{L}$ was fortuitous, a nutrient medium with $135 \mathrm{mg} \mathrm{N} / \mathrm{L}$ and 24\% salinity allows using the higher amount of centrate without affecting $C x$, thus these were the characteristics of the culture medium chosen for $N$. oculata cultivation.

\subsection{Microalgae cultivation in flat-panel airlift PBR}

\subsubsection{Chlorella kessleri cultivation}

The microalgae were cultured in $1 \mathrm{~L}$ PBR to evaluate the microalgae growth, the nutrient removal and the biomass production. Fig. 2a shows C. kessleri growth as the evolution of the number of cells over time in a culture medium with $130 \mathrm{mg} \mathrm{N} / \mathrm{L}(0.009 \mathrm{~mol} / \mathrm{L})$, and Fig. $2 \mathrm{~d}$ shows the $\mathrm{N}$ evolution as the percentage of the initial $\mathrm{N}$ which remained in the culture medium, and the Cx evolution in the culture.

As can be observed in Fig. 2a, there was a scarce microalgae growth during the first two days but the algal dry weight slightly increased, indicating microalgae cell size increase. This cell size increase was accompanied by a TN concentration reduction from $130.0 \pm 0.3 \mathrm{mg} \mathrm{N} / \mathrm{L}$ to $108.2 \pm 0.3 \mathrm{mg} \mathrm{N} / \mathrm{L}$, which represented $\sim 16 \% \mathrm{TN}$ consumption. After the 2nd day, the microalgae growth started a steady increase until the 7th day. At this time, the $\mathrm{Cx}$ in the reactor reached $1.78 \pm 0.05 \mathrm{~g} / \mathrm{L}$; the total TN consumption was $\sim 95 \%$, the remaining TN concentration was under the limits for the TN discharge [6]. The microalgae growth continued until it reached the stationary phase on the 9th day. Although there was not a significant TN consumption after the 7th day, the $\mathrm{CX}$ reached $2.34 \pm 0.01 \mathrm{~g} / \mathrm{L}$ on the 9th day and $2.70 \pm 0.08 \mathrm{~g} / \mathrm{L}$ at the end of the experiment. The final TN concentration was lower than $5 \mathrm{mg} \mathrm{N} / \mathrm{L}$, which meant $>96 \%$ removal. Regarding $\mathrm{P}$ as a nutrient, the initial concentration of TP in growth medium was $5.76 \pm 0.08 \mathrm{mg} \mathrm{P} / \mathrm{L}$, and at the end of the experiment $0.04 \pm 0.01 \mathrm{mg} \mathrm{P} / \mathrm{L}$, which indicated more than $99 \%$ removal efficiency. Under the culture conditions in this experiment, $C$. kessleri showed a high efficiency at removing TN and TP; the culture conditions affect TN and TP removal differently [7]. The results indicated that C. kessleri cultivation can remove TN and TP without a previous acclimation step; a microalgae acclimation step was unnecessary to improve nutrient removal as it is suggested in the literature [25]. Similar results were also reported by Arbib et al. [13]. The N/P ratio in the culture media was 23 , higher than the range 6.8-10 indicated as optimal for freshwater microalgae cultivation [9]. As some other freshwater microalgae species [9], C. kessleri has demonstrated the ability of growing in nutrient media with an unbalanced N/P ratio.

Based on the stoichiometric needs of biomass and nutrient concentration in the medium, the maximal biomass concentration without starvation was calculated. Assuming an elemental composition of biomass equal to $\mathrm{CH}_{1.715} \mathrm{O}_{0.427} \mathrm{~N}_{0.148} \mathrm{~S}_{0.014} \mathrm{P}_{0.012}$, where the $\mathrm{C}$-molar mass is $23.45 \mathrm{~g} \mathrm{C} / \mathrm{mol}$ [16], and an initial TN concentration of $130 \mathrm{mg} / \mathrm{L}$, the maximal biomass concentration without starvation resulted to $2.18 \mathrm{~g} / \mathrm{L}$. As can be seen in Fig. 2d (dashed line), this concentration was reached between the 7th and 8th days of cultivation. In the same period, it remained less than $5 \%$ of the initial TN concentration (Fig. 2b), indicating that microalgae cells may experience $\mathrm{N}$-starvation.

Fig. 3 indicates the microalgae spectra obtained during FTIR analyses, for biomass collected during the 2nd, 6th and 9th days, corresponding to the beginning of the exponential phase, when the TN concentration in the culture medium was $\sim 5 \mathrm{mg} \mathrm{N} / \mathrm{L}$, and at the beginning of the stationary phase.

Since the lipids, protein and carbohydrates can be identified due to their characteristic groups [26], the comparison of the three spectra in Fig. 3 shows the evolution of the proteins, carbohydrates and lipids in biomass. The protein content decreased during cultivation, due to less intensified absorption bands at $1500-1700 \mathrm{~cm}^{-1}$ for peptide amide groups of proteins. On the contrary, the absorption bands at 1000 $1200 \mathrm{~cm}^{-1}$, characteristics of C-O and C-O-C groups of carbohydrates, increased. Moreover, more intensified bands at $1700-1750 \mathrm{~cm}^{-1}$ and $2800-3000 \mathrm{~cm}^{-1}$, characteristics for lipids indicated a lipid content increase. These changes in the absorption bands indicated that the 

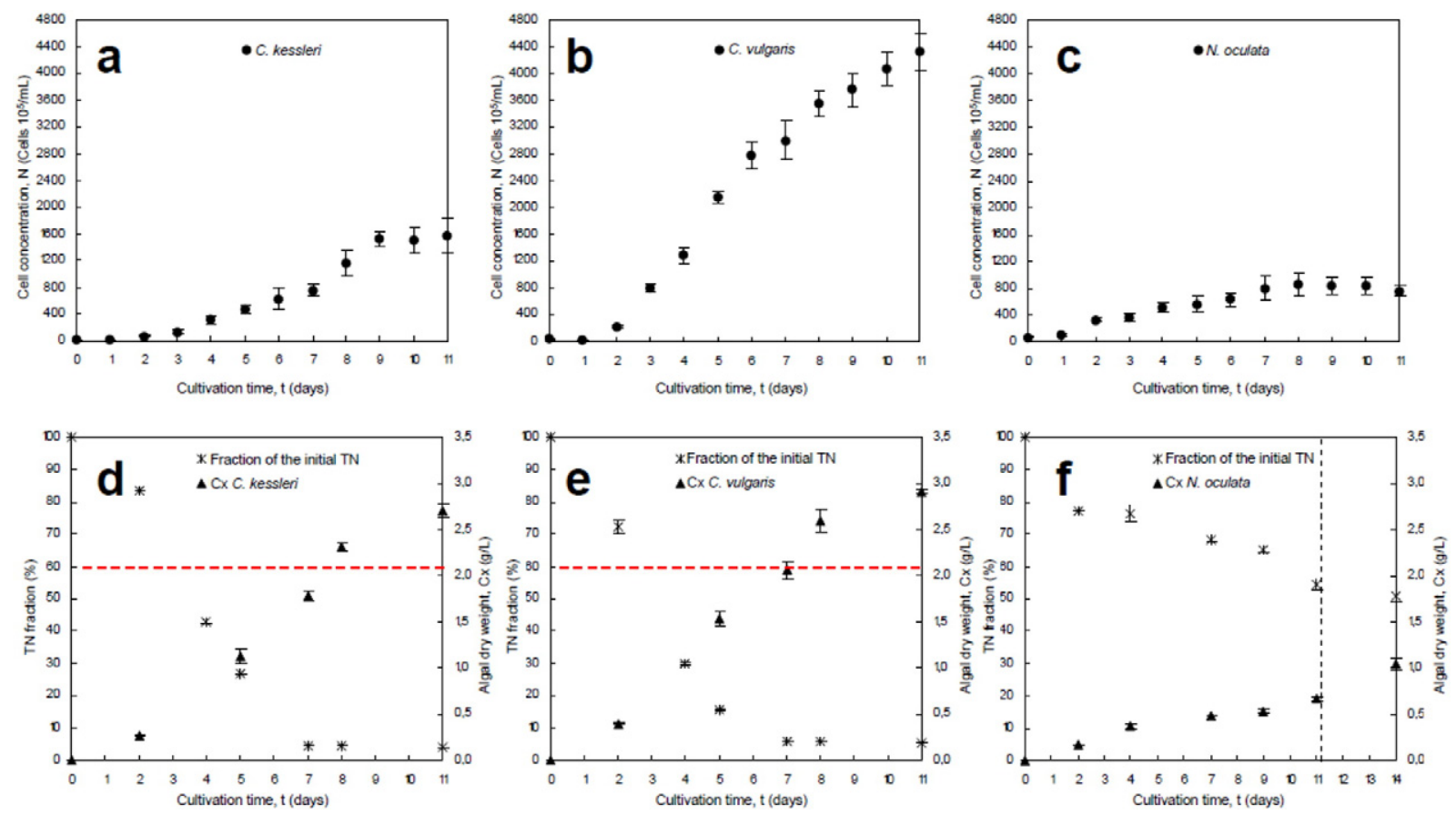

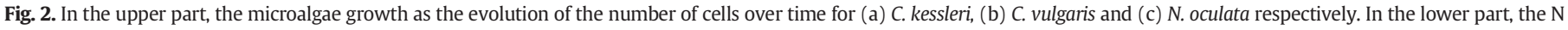

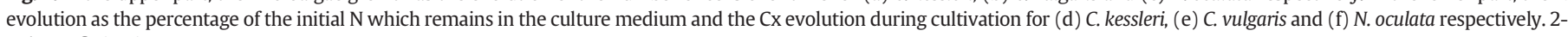
Column fitting image.

microalgae underwent a period of N-starvation; the cell division decreased progressively, the dry weight increase became lower and the lipid content triggers. These facts, visible in Figs. 2a and d and 3, were also observed in other freshwater microalgae species which experienced progressive N-starvation [16]. The results confirmed that the microalgae cultivation in wastewater follows a progressive $\mathrm{N}$ starvation process, increasing the microalgae lipid content, valuable for biofuels production. The total lipid content was not analysed, and the saponifiable lipid fraction (convertible into biodiesel) was quantified instead; the saponifiable lipid content yielded $7.4 \pm 0.2 \mathrm{~g} / 100 \mathrm{gvs}$. The content of proteins and carbohydrates in C. kessleri were $36.7 \pm$ $1.0 \mathrm{~g} / 100 \mathrm{~g}_{\mathrm{vs}}$ and $44.6 \pm 0.1 \mathrm{~g} / 100 \mathrm{~g}_{\mathrm{vs}}$ respectively.

\subsubsection{Chlorella vulgaris cultivation}

C. vulgaris growth in a culture medium with $130 \mathrm{mg} \mathrm{N} / \mathrm{L}$ $(0.009 \mathrm{~mol} / \mathrm{L})$ can be observed in Fig. $2 \mathrm{~b}$ as the evolution of the

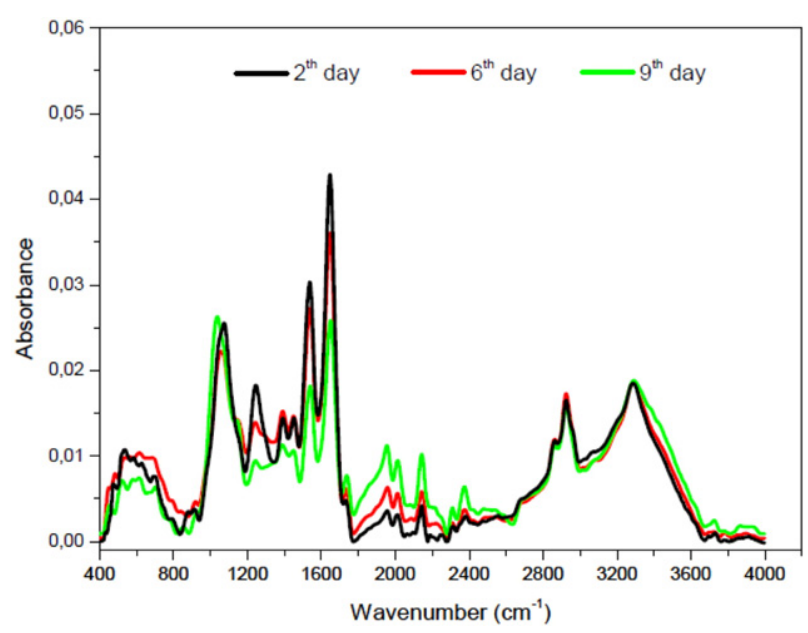

Fig. 3. FTIR spectra of $C$. kessleri microalgae collected during the 2 nd, 6 th and 9 th days. Single-column fitting image. number of cells over time; the $\mathrm{N}$ evolution as the percentage of the initial $\mathrm{N}$ which remained in the culture medium and the $\mathrm{Cx}$ evolution in the culture can be observed in Fig. 2e.

Similar to C. kessleri, the number of cells did not change until the second day but the algal dry weight increase revealed a cells size increase. This was accompanied by a $27 \%$ consumption of the TN; the TN concentration decreased from $130.0 \pm 0.3 \mathrm{mg} \mathrm{N} / \mathrm{L}$ to $93.4 \pm 2.5 \mathrm{mg} \mathrm{N} / \mathrm{L}$. From the 2nd day until the 6th day, the microalgae growth showed a steady increase. After the 6th day, the growth rate decreased and on the 11th day the culture was near the steady phase. The $\mathrm{Cx}$ in the reactor increased daily and it reached $2.63 \pm 0.09 \mathrm{~g} / \mathrm{L}$ the 8 th day, when the TN consumption was 94\% and the TN level lower than $10 \mathrm{mg} \mathrm{N} / \mathrm{L}$ required for water discharge [6]. The subsequent number of cell increase was not accompanied by substantial $\mathrm{Cx}$ increase or $\mathrm{N}$ consumption; in fact, the $\mathrm{Cx}$ and the TN consumptions reached $2.91 \pm 0.02 \mathrm{~g} / \mathrm{L}$ and $\sim 95 \%$ respectively. At the end of the experiment, TP in growth medium was $0.11 \pm 0.02 \mathrm{mg} \mathrm{P} / \mathrm{L}$, lower than the threshold established by the European Directive $(<1 \mathrm{mg} \mathrm{P} / \mathrm{L}$ ) [6], resulting in a removal efficiency higher than 98\%. The results also indicated that $C$. vulgaris grows in wastewater, even when the $\mathrm{N} / \mathrm{P}$ ratio is unbalanced and higher than the indicated as optimal for freshwater microalgae cultivation [9]. The nutrients removal efficiencies were higher than the reported after $C$. vulgaris cultivation in wastewater sampled in different point of a WWTP, including centrate samples with a similar composition than in the present experiment [9]. Although similar nutrient removals were reported in wastewater mixed with glycerol, the biomass concentration reported at the end of the experiment was considerably lower [10]. Comparable nutrients removals and lower biomass production were reported during the $C$. vulgaris cultivation using centrate obtained from a digester processing cattle slurry and raw cheese whey [11].

As during $C$. kessleri cultivation, $C$. vulgaris experienced a progressive $\mathrm{N}$-starvation process, which led biomass to a cell division decrease, a low dry weight increase and a total lipid content accumulation. The maximal biomass concentration without starvation resulted in $2.18 \mathrm{~g} / \mathrm{L}[16]$ and it is indicated in Fig. 2e by a dashed line. This biomass concentration was reached between the 7 th and 8 th day of cultivation, when the TN concentration was less than the $5 \%$ of the initial 
concentration. After this period, the microalgae increased their lipid content. The saponifiable lipid fraction yielded $11.3 \pm 0.1 \mathrm{~g} / 100 \mathrm{~g}_{\mathrm{vs}}$ at the end of the experiment, similar to the results reported for the same C. vulgaris strain cultivation under $\mathrm{N}$-starvation [17]. The content of proteins and carbohydrates in C. vulgaris were $35.2 \pm 1.4 \mathrm{~g} / 100 \mathrm{~g}$ vs and $36.2 \pm 0.3 \mathrm{~g} / 100 \mathrm{~g}_{\mathrm{vs}}$ respectively.

A comparison between $C$. kessleri and $C$. vulgaris shows a significant difference in the number of cells. C. kessleri reached around $1500 \cdot 10^{5}$ cells $/ \mathrm{mL}$ at the end of the experiment, whereas C. vulgaris reached almost three times this number (Fig. 2a and b). However, the $\mathrm{Cx}$ was in both species, which agrees with the larger size of the $C$. kessleri cells compared with the $C$. vulgaris cells. The higher cell size in $C$. kessleri may increase harvesting efficiency, thus being beneficial from an engineering point of view. The literature comparing $C$. kessleri and $C$. vulgaris for wastewater treatment is scarce, but both species have shown a similar biomass production when cultured under the same conditions [13]. However, the reported biomass production was lower than the $2.70 \pm 0.08 \mathrm{~g} / \mathrm{L}$ and the $2.91 \pm 0.02 \mathrm{~g} / \mathrm{L}$ obtained for C. kessleri and C. vulgaris respectively in the present studio.

Chlorella microalgae are usually found in wastewater treatment ponds [8], suggesting that can uptake nutrients from wastewater to grow. The species cultured in this study shows a promising future for nutrient removal in wastewaters. Moreover, the biomass cultivation makes possible the centrate utilization as nutrient medium instead of its recirculation to a previous step in the process. The biomass can be used as fertiliser, as animal feed or as biofuel feedstocks, being economically advantageous for the WWTP [8]. Moreover, the progressive Nstarvation during cultivation triggers lipid accumulation in biomass, attractive for biofuels production [17].

\subsubsection{Nannochloropsis oculata cultivation}

$N$. oculata was grown in a nutrient medium with $\sim 100 \mathrm{mg} \mathrm{N} / \mathrm{L}$ $(0.007 \mathrm{~mol} / \mathrm{L})$ and $25 \%$ salinity. Due to the higher TN concentration in the centrate collected for this experiment, it was possible to increase the TN concentration in the nutrient medium, keeping salinity in the optimum range [22]. The evolution of the number of cells over time can be observed in Fig. 2c. The $\mathrm{N}$ evolution and the $\mathrm{Cx}$ evolution in the culture can be observed in Fig. 2f.

Fig. 2c shows that there was not a significant lag phase at the beginning of the experiment; the number of cells increased at an almost constant rate from the beginning until the 8th day. After the 8th day, it started a stationary phase followed by a declination phase derive from the biomass precipitation observed. The stationary phase started the 8th day; the TN concentration was $67.0 \pm 0.8 \mathrm{mg} \mathrm{N} / \mathrm{L}$, which barely represented $\sim 35 \%$ consumption of the initial $102.8 \pm 0.1 \mathrm{mg} \mathrm{N} / \mathrm{L}$. On the 11th day, the TN concentration reached $55.9 \pm 2.0 \mathrm{mg} \mathrm{N} / \mathrm{L}, \sim 47 \%$ consumption; the TN concentration in the culture medium exceeded the limit required for water discharge [6] but to prolong the cultivation beyond did not increase the $\mathrm{N}$ consumption significantly. The experiment was conducted until the 14th day due to the low $\mathrm{N}$ consumption observed; however, the number of cells was not counted beyond the 11 th day. The $C x$ increased at an almost constant rate from the beginning of the experiment until the end of the experiment; the 11th day, the $C x$ reached $0.66 \pm 0.02 \mathrm{~g} / \mathrm{L}$ and on the 14 th day, $1.05 \pm 0.06 \mathrm{~g} / \mathrm{L}$ despite there was not any $\mathrm{N}$ consumption in this period. The $\mathrm{Cx}$ values were considerably lower compared with the Cx obtained in the freshwater microalgae cultivation (Fig. $2 \mathrm{~d}$ and e). The TP concentration at the end of the experiment was $0.04 \pm 0.01 \mathrm{mg} \mathrm{P} / \mathrm{L}$, lower than the threshold established by the European Directive ( $<1 \mathrm{mg} \mathrm{P} / \mathrm{L})$, resulting in a removal efficiency higher than $96 \%$ [6].

Nannochloropsis species have shown the capability to grow in different nutrient media varying nitrogen concentration, salinity, ph, light intensities, between some other factors [14,15,23]. It has been reported that the microalgae grows without major changes in a medium with $\mathrm{N} / \mathrm{P}$ ratio of 32, although the optimal ratio is 16 [27]. The initial N/P ratio was considerably higher than the optimal, around 100 . The excess or lack of P influences negatively the cell division and the biomass productivity [27]; thus affecting the microalgae growth and the $\mathrm{N}$ consumption.

Although $N$. oculata grows in wastewater, the results suggest that the aim of the wastewater utilisation should be established in advance. If cultivation is aimed to reduce nutrient content, the freshwater microalgae species are preferable; the nitrogen level at the end of $N$. oculata cultivation still exceeds the threshold established by the European Directive for water discharge. However, if cultivation is aimed at biofuels production or valuable compound production from marine microalgae species instead, centrate can replace nutrient addition reducing the production costs. In this case, the salinity needs to be adjusted in order to obtain high biomass productivities.

\subsection{Methane production from microalgae}

C. kessleri and C. vulgaris grown in wastewater were recovered from the PBR and anaerobically digested in order to evaluate their potential as substrate for methane production. The methane production curves from C. kessleri and C. vulgaris are shown in Fig. 4.

The methane production was similar for both microalgae species during the first four days, becoming different after this period. On the 6th day, the methane production from $C$. vulgaris was $11 \%$ higher than from C. kessleri. This difference progressively increased until the end of the experiment, when it reached $20 \%$. The final methane production from C. kessleri and C. vulgaris were $346 \pm 3 \mathrm{~mL}_{\mathrm{CH}_{4}} / \mathrm{g}_{\mathrm{vs}}$ and $415 \pm 2 \mathrm{~mL}_{\mathrm{CH}_{4}} /$ $\mathrm{g}_{\mathrm{vs}}$ respectively. For C. kessleri, it has been reported $218 \mathrm{~mL}_{\mathrm{CH}_{4}} / \mathrm{g}_{\mathrm{vs}}$ under mesophilic conditions; for C. vulgaris digestion, $240 \mathrm{~mL}_{\mathrm{CH}_{4}} / \mathrm{g}_{\mathrm{vs}}$ and $286 \mathrm{~mL}_{\mathrm{CH}_{4}} / \mathrm{g}_{\mathrm{vs}}$ were reported after 28 days and 49 days mesophilic conditions respectively [4]; however, there is no literature relating to the anaerobic digestion of microalgae cultivated in wastewaters. These methane productions were clearly exceeded in the present experiment. What is more, the methane productions obtained are higher than those reported for several microalgae species [4]. Even more interesting results appear when comparing the methane production from microalgae with substrates commonly used in anaerobic digestion, such as sewage sludge, which under similar conditions produced around $350 \mathrm{~mL}_{\mathrm{CH}_{4}} / \mathrm{g}_{\mathrm{vs}}$ [19]. The methane production from several substrates such as municipal solid wastes, swine manure, maize silage and straw, etc., was also exceeded [4].

The theoretical methane production resulted in $533 \pm 5 \mathrm{~mL}_{\mathrm{CH}_{4}} / \mathrm{g}_{\mathrm{vs}}$ and $567 \pm 1 \mathrm{~mL}_{\mathrm{CH}_{4}} / \mathrm{g}_{\mathrm{vs}}$ for $C$. kessleri and C. vulgaris respectively. The biodegradability resulted in $65 \%$ and $66 \%$ for $C$. kessleri and $C$. vulgaris respectively, higher than the values reported for other microalgae species

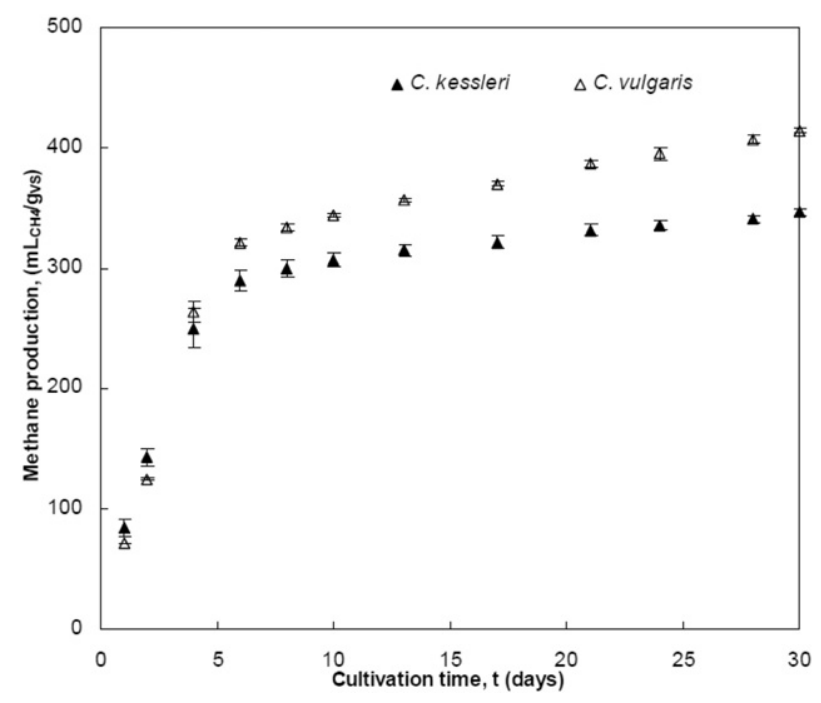

Fig. 4. Methane production curves from C. kessleri and C. vulgaris cultivated in wastewater, batch reactors and $33^{\circ} \mathrm{C}$. Single-column fitting image. 
and similar to the values reported for sewage sludge mesophilic digestion $[4,19]$. The values of $\mathrm{pH}$, alkalinity, and concentration of ammonia and VFA were measured at the end of the experiments corroborated that the digesters operated at optimum conditions. The biogas composition, analysed several times during the experiments, indicated that the methane percentage ranged between $66 \%$ and $71 \%$ in all reactors.

The methane production from both microalgae species shows that biomass cultivation in wastewater coupled to anaerobic digesters allows wastewater treatment and energy recovery simultaneously. During the wastewater treatment process, the TN concentration reduction can lead to high lipid content in biomass; a high lipid content increases the methane production potential of the biomass.

\subsection{Biodiesel production from microalgae}

The FAME content in freeze-dried C. kessleri and C. vulgaris grown in wastewater was quantified, to evaluate suitability of the microalgae for biodiesel application.

The biodiesel yields obtained from C. kessleri and C. vulgaris amounted to $7.4 \pm 0.2 \mathrm{~g} / 100 \mathrm{~g}_{\mathrm{vs}}$ and $11.3 \pm 0.1 \mathrm{~g} / 100 \mathrm{~g}_{\mathrm{vs}}$ respectively. These results are comparable to the results obtained from Chlorella sp. reported elsewhere $[7,28]$. Although the biodiesel yields for both microalgae strains were not high enough for industrial biodiesel production, changes in microalgae cultivation conditions can enhance the accumulation of lipids and the biodiesel yields [29]. The biodiesel yield in C. vulgaris was also similar to results found during the cultivation of the same strain under $\mathrm{N}$-starvation [17], confirming that the $\mathrm{N}$-starvation increased the lipid content during cultivation in wastewater. Moreover, the fatty acid profiles of both microalgae strains were dominated by palmitic (C16:0), oleic (18:1), linoleic (C18:2) and linolenic (C18:3) acids; these fatty acids are the most common fatty acids contained in biodiesel produced from vegetable oils [30]. Fatty acid profile of $C$. kessleri consisted of $20.3 \%, 10.4 \%, 32.2 \%$ and $12.9 \%$ of palmitic, oleic, linoleic and linolenic acid, respectively. C. vulgaris contained $22.2 \%, 27.2 \%, 11.6 \%$ and $10.6 \%$ of palmitic, oleic, linoleic and linolenic acid, respectively.

Both microalgae cultivated in wastewater are suitable sources of lipids for biodiesel production, contrary to some other microalgae species with a high content of polyunsaturated fatty acids, which decreases oxidative stability of biodiesel [29,31]. The anaerobic digestion of microalgae wastes from biodiesel production was not evaluated. However, the idea of coupling biodiesel production and anaerobic digestion of the microalgae wastes might be a way to improve the global efficiency of biodiesel production.

\section{Conclusions}

The centrate from a WWTP was found interesting to supply nutrients for microalgae cultivation. The freshwater microalgae species C. kessleri and C. vulgaris removed $\mathrm{N}$ and $\mathrm{P}$ almost completely ( $>95 \%)$; the progressive $\mathrm{N}$-starvation derived from $\mathrm{N}$ consumption lead to a biomass with a high potential for methane production. Moreover, the biodiesel produced from both species showed interesting properties, indicating the possibility of producing this biofuel. Under the cultivation condition evaluated, $N$. oculata showed a low efficiency at nutrient removal; in order to obtain higher nutrient removal or higher biomass production for valuable compounds, cultivation must be optimised.

\section{Acknowledgements}

Martín Pablo Caporgno thanks the Spanish Ministerio de Educación, Cultura y Deporte for his pre-doctoral scholarship (Ref. AP2012-3726) and for his mobility scholarship (Ref. EST13/00384). Financial support for this research was provided by the Spanish Ministerio de Educación y Ciencia and FEDER, project CTM2011-23069, and by the French National Research Agency, project DIESALG (ANR-12-BIME-0001-02). The authors thank "CARENE/Saint-Nazaire agglomeration" (WWTP of
Saint-Nazaire, France) and Gestió Ambiental i Abastament S.A. Company (WWTP of Reus, Spain) for their kind collaboration during this project. Finally, Martín Pablo Caporgno also thanks all the personnel from the GEPEA Laboratory, Université de Nantes, who kindly helped during his research stay.

\section{References}

[1] L. Brennan, P. Owende, Biofuels from microalgae-a review of technologies for production, processing, and extractions of biofuels and co-products, Renew. Sust. Energ. Rev. 14 (2010) 557-577.

[2] T.M. Mata, A.A. Martins, N.S. Caetano, Microalgae for biodiesel production and other applications: a review, Renew Sust Energ. Rev 14 (2010) 217-232.

[3] I. Rawat, R.R. Kumar, T. Mutanda, F. Bux, Biodiesel from microalgae: a critical evaluation from laboratory to large scale production, Appl. Energy 103 (2013) 444-467.

[4] E. Kwietniewska, J. Tys, Process characteristics, inhibition factors and methane yields of anaerobic digestion process, with particular focus on microalgal biomass fermentation, Renew. Sust. Energ. Rev. 34 (2014) 491-500.

[5] L. Appels, J. Baeyens, J. Degrève, R. Dewil, Principles and potential of the anaerobic digestion of waste-activated sludge, Prog. Energy Combust. 34 (2008) 755-781.

[6] European Union law, Commission Directive 98/15/EC. Official Journal of the European Communities, http://eur-lex.europa.eu/legalcontent/EN/TXT/PDF/?uri= CELEX:31998L0015\&from $=$ EN1998

[7] Y. Li, W. Zhou, B. Hu, M. Min, P. Chen, R.R. Ruan, Integration of algae cultivation as biodiesel production feedstock with municipal wastewater treatment: strains screening and significance evaluation of environmental factors, Bioresour. Technol. 102 (2011) 10861-10867.

[8] J.K. Pittman, A.P. Dean, O. Osundeko, The potential of sustainable algal biofuel production using wastewater resources, Bioresour. Technol. 102 (2011) 17-25.

[9] L. Wang, M. Min, Y. Li, P. Chen, Y. Chen, Y. Liu, Y. Wang, R. Ruan, Cultivation of green algae Chlorella sp. in different wastewaters from municipal wastewater treatment plant, Appl. Biochem. Biotechnol. 162 (2010) 1174-1186.

[10] I.T. Dominguez Cabanelas, Z. Arbib, F.A. Chinalia, C. Oliveira Souza, J.A. Perales, P.F. Almeida, J. Izabel Druzian, I. Andrade Nascimento, From waste to energy: microalgae production in wastewater and glycerol, Appl. Energy 109 (2013) 283-290.

[11] M. Franchino, E. Comino, F. Bona, V.A. Riggio, Growth of three microalgae strains and nutrient removal from an agro-zootechnical digestate, Chemosphere 92 (2013) 738-744.

[12] P.J. He, B. Mao, C.M. Shen, L.M. Shao, D.J. Lee, J.S. Chang, Cultivation of Chlorella vulgaris on wastewater containing high levels of ammonia for biodiesel production, Bioresour. Technol. 129 (2013) 177-181.

[13] Z. Arbib, J. Ruiz, P. Álvarez-Díaz, C. Garrido-Pérez, J.A. Perales, Capability of different microalgae species for phytoremediation processes: wastewater tertiary treatment, $\mathrm{CO}_{2}$ bio-fixation and low cost biofuels production, Water Res. 49 (2014) 465-474

[14] L. Jiang, S. Luo, X. Fan, Z. Yang, R. Guo, Biomass and lipid production of marine microalgae using municipal wastewater and high concentration of $\mathrm{CO}_{2}$, Appl. Energy 88 (2011) 3336-3341.

[15] T. Cai, S.Y. Park, R. Racharaks, Y. Li, Cultivation of Nannochloropsis salina using anaerobic digestion effluent as a nutrient source for biofuel production, Appl. Energy 108 (2013) 486-492.

[16] J. Pruvost, G. Van Vooren, G. Cogne, J. Legrand, Investigation of biomass and lipids production with Neochloris oleoabundans in photobioreactor, Bioresour. Technol. 100 (2009) 5988-5995.

[17] J. Pruvost, G. Van Vooren, B. Le Gouic, A. Couzinet-Mossion, J. Legrand, Systematic investigation of biomass and lipid productivity by microalgae in photobioreactors for biodiesel application, Bioresour. Technol. 102 (2011) 150-158.

[18] A. Taleb, J. Pruvost, J. Legrand, H. Marec, B. Le-Gouic, B. Mirabella, B. Legeret, S. Bouvet, G. Peltier, Y. Li-Beisson, S. Taha, H. Takache, Development and validation of a screening procedure of microalgae for biodiesel production: application to the genus of marine microalgae Nannochloropsis, Bioresource Technol. 177 (2015) 224-232.

[19] M.P. Caporgno, R. Trobajo, N. Caiola, C. Ibáñez, A. Fabregat, C. Bengoa, Biogas production from sewage sludge and microalgae co-digestion under mesophilic and thermophilic conditions, Renew. Energy 75 (2015) 374-380.

[20] E.W. Rice, R.B. Baird, A.D. Eaton, L.S. Clesceri, Standard methods for the examination of water and wastewater, 22nd ed. APHA, AWWA, WEF, 2012.

[21] M.B. Johnson, Z. Wen, Production of biodiesel fuel from the microalga Schizochytrium limacinum by direct transesterification of algal biomass, Energy Fuels 23 (2009) 5179-5183.

[22] N. Gu, Q. Lin, G. Li, G. Qin, J. Lin, L. Huang, Effect of salinity change on biomass and biochemical composition of Nannochloropsis oculata, J. World Aquacult. Soc. 43 (2012) 97-106.

[23] H. Khatoon, N.A. Rahman, S. Banerjee, N. Harun, S.S. Suleiman, N.H. Zakaria, F Lananan, S.H.A. Hamid, A. Endut, Effects of different salinities and $\mathrm{pH}$ on the growth and proximate composition of Nannochloropsis sp. and Tetraselmis sp. isolated from South China Sea cultured under control and natural condition, Int. Biodeterior. Biodegrad. A 95 (Part A) (2014) 11-18.

[24] E.W. Becker, Microalgae: biotechnology and microbiology, Cambridge University Press, 2008.

[25] O. Osundeko, A.P. Dean, H. Davies, J.K. Pittman, Acclimation of microalgae to wastewater environments involves increased oxidative stress tolerance activity, Plant Cell Physiol. 55 (2014) 1848-1857. 
[26] M.A. Pistorius, W.J. DeGrip, T.A. Egorova-Zachernyuk, Monitoring of biomass composition from microbiological sources by means of FT-IR spectroscopy, Biotechnol. Bioeng. 103 (2008) 123-129.

[27] J.J. Mayers, K.J. Flynn, R.J. Shields, Influence of the N:P supply ratio on biomass productivity and time-resolved changes in elemental and bulk biochemical composition of Nannochloropsis sp. Bioresour. Technol. 169 (2014) 588-595.

[28] Y. Li, Y. Chen, P. Chen, M. Min, W. Zhou, B. Martinez, J. Zhu, R. Ruan, Characterization of a microalga Chlorella sp. well adapted to highly concentrated municipal wastewater for nutrient removal and biodiesel production, Bioresour. Technol. 102 (2011) 5138-5144.
[29] G. Van Vooren, F. Le Grand, J. Legrand, S. Cuiné, G. Peltier, J. Pruvost, Investigation of fatty acids accumulation in Nannochloropsis oculata for biodiesel application, Bioresour. Technol. 124 (2012) 421-432.

[30] G. Knothe, "Designer" biodiesel: optimizing fatty ester composition to improve fuel properties, Energy Fuels 22 (2008) 1358-1364.

[31] S.D. Ríos, J. Castañeda, C. Torras, X. Farriol, J. Salvadó, Lipid extraction methods from microalgal biomass harvested by two different paths: Screening studies toward biodiesel production, Bioresour. Technol. 133 (2013) 378-388. 